\title{
Factors Influencing Green Entrepreneurship of Returning Migrant Workers under the Dual-Carbon Background
}

\author{
Li Beiwei, ${ }^{1}$ Yue Zhengliang $\mathbb{D D}^{1,2}$ and Liu Hongtao ${ }^{2}$ \\ ${ }^{1}$ School of Management, Jilin University, Changchun City, Jilin Province, China \\ ${ }^{2}$ Zhuhai College of Science and Technology, Zhuhai City, Guangdong Province, China \\ Correspondence should be addressed to Yue Zhengliang; yuezhengliang@zcst.edu.cn
}

Received 15 January 2022; Revised 26 January 2022; Accepted 27 January 2022; Published 21 February 2022

Academic Editor: Thippa Reddy G

Copyright (c) $2022 \mathrm{Li}$ Beiwei et al. This is an open access article distributed under the Creative Commons Attribution License, which permits unrestricted use, distribution, and reproduction in any medium, provided the original work is properly cited.

China's rural energy consumption structure has dominated by coal, and carbon dioxide emissions are relatively large. Under the dual historical responsibilities of the carbon peak, the carbon neutral dual-carbon, and the rural revitalization strategy, the rural energy transition is imminent. This paper conducts an in-depth study on the green entrepreneurship of migrant workers returning to their hometowns and carefully analyzes the factors affecting the return of migrant workers to green entrepreneurship. This paper establishes a regression model to clarify that the green entrepreneurial guidance mechanism can effectively increase entrepreneurial opportunities, promote the rational allocation of regional resources, increase the success rate of entrepreneurship, and promote the construction of new rural areas in China with proper healthcare. The implementation of the scientific guidance mechanism for migrant workers' green entrepreneurship should adhere to the scientific development concept, correctly guide farmers to return to their hometowns to start businesses, and provide them with a green channel for fiscal taxation. Green entrepreneurship can improve the entrepreneurial ability of migrant workers in order to effectively increase the success rate of migrant workers in entrepreneurship, ensure the rational use of regional resources, and promote the harmonious and stable development of society.

\section{Introduction}

As global climate change poses a major threat to human society, more and more countries have elevated "carbon neutrality" as a national strategy and proposed a vision for a carbon-free future. The "dual-carbon" target proposed has a profound domestic and foreign development background, which will definitely have a profound impact on the economy and society. The realization of the "dual-carbon" goal should have been comprehensively considered and dealt with in the overall strategic of promoting high-quality development and comprehensive modernization. China has become the world's second largest economy, a leader in green economy and technology, and its global influence continues to expand. Facts have proved that only by making the development mode greener can we adapt to the laws of nature. To this end, in 2020, based on the inherent requirements of promoting sustainable development and the responsibility, China announced the goal of achieving carbon peaks and carbon neutrality. General Secretary Xi Jinping emphasized that carbon peaking and carbon neutrality should have been incorporated into the overall layout of ecological civilization construction that can help in improving the healthcare of the citizens $[1,2]$. It is necessary to promote major breakthroughs in green and low-carbon technologies, promptly deploy low-carbon cutting-edge technology research, accelerate the promotion and application of pollution reduction and carbon reduction technologies, and establish and improve green and low-carbon technology evaluation, trading system, and technological innovation service platform. In the future, China will form a greener, more efficient, and sustainable consumption and productivity model for sustainable development and jointly composing the ecology in civilization.

As China's economic structure and industrial development are in an important period of transformation, Premier Li Keqiang proposed the development strategy of "mass entrepreneurship and innovation." Many migrant workers 
with knowledge, vision, and skills have chosen to return and set up entrepreneurship through the funds and some experience they have accumulated during their migrant work period, making migrant workers the group with the most potential and enthusiasm in entrepreneurship and innovation. However, looking at the living conditions of migrant workers who have not yet returned to their hometowns, they still have many worries about the behavior of returning to set up entrepreneurship, which have been seriously affected by many factors of themselves and the outside world. The return of migrant workers to set up entrepreneurship in their hometown is conducive to proposing more targeted countermeasures, which plays a vital role in enhancing migrant workers' enthusiasm for returning to their hometown, promoting successful entrepreneurship, and promoting rural modernization. Entrepreneurship is an important engine for economic growth and social development [3]. Since 2015, China has increased its strategic support for rural revitalization and issued a series of policy documents to support entrepreneurship. China Council has also incorporated migrant workers' return to their hometowns to set up entrepreneurship, which promotes economic development in the unified deployment of the "double entrepreneurship" strategy. As a result, the "returning goose economy" driven by the return of migrant workers to their hometowns to set up entrepreneurship has quietly risen across the country [4]. The migrant workers returning to their hometowns are large in scale, rich in social experience, and highly skilled. Many migrant workers have seen the potential for future development in their hometowns and have returned to their hometowns to set up entrepreneurship. The return of migrant workers is an important part of China's "double innovation" and an important way to accelerate the construction of new urbanization and fully promote the "village revitalization" strategy [4].

Previous studies mainly focus on the determinants of migrant workers returning to set up entrepreneurship in the structural reform of the agricultural supply side, continue to activate the rural economy, and ultimately achieve rural revitalization [5]. But, quantitative analysis is lacking, and the green entrepreneurial behavior index of migrant workers is also very small. Therefore, it is an urgent task to describe the influencing factors in detail. In this research, migrant workers return to their hometown to set up green entrepreneurship. Under the current background of building an ecologically civilized society and achieving sustainable development, the enterprise adopts advanced technology and reformed management methods to implement green in the entire production and operation process. This paper establishes a measurement model of the green entrepreneurial behavior index of migrant workers returning home. Based on this, this paper studies the factors that affect the green entrepreneurial behavior of migrant workers returning to their hometowns, which can create favorable conditions for green entrepreneurship, further promote the development of green entrepreneurial activities, and help achieve the goal of China's ecological civilization society. Therefore, this paper contributes to study the green entrepreneurial behaviors and influencing factors of migrant workers returning to their hometowns. This article has certain reference value for formulating relevant policies to promote the green entrepreneurship and achieve green development.

\section{Related Theories}

Green entrepreneurship has gradually merged with other disciplines and themes, and theoretical research on the connotation and types of green entrepreneurship has been greatly enriched. Some scholars have combined green entrepreneurship with social practice research and proposed a green entrepreneurial operation model to provide guidance for companies to achieve green production and increase green benefit. The research on green entrepreneurship in western countries started early and has produced certain results in the research of green entrepreneurship [6]. Domestic scholars mainly use different perspectives and methods to study the theories and types of green entrepreneurship based on the theoretical results of foreign green entrepreneurship research. In-depth analysis was carried out, and at the same time, some scholars discussed the current problems facing enterprises' green entrepreneurship and provided solutions for the realization of sustainable development [7]. From the emergence of green entrepreneurship, to the construction of green entrepreneurship theory and its combination with practical research, relevant literature has begun enriching. Table 1 shows related works as follows.

2.1. The Background of Dual-Carbon Construction. On the international front, the world's economic development has accelerated the conversion of old and new kinetic energy, and the development of clean and low-carbon energy has become a global consensus. In July 2020, before the EU announced its carbon neutral plan, more than 30 countries had announced carbon neutral targets, including Mexico and the Maldives. Since then, China, Japan, and South Korea have successively proposed carbon neutral goals. US President-Elect Biden also proposed in his speech that the United States should return to the "Paris Agreement." The basic requirement is that the United States should propose a timetable and roadmap for carbon neutrality. In this way, the world's important economies, which account for $75 \%$ of global GDP and 65\% of global carbon emissions, become carbon neutral [8]. China is also a major energy consumer. Its commitment to carbon peaking and carbon neutrality fully reflects the responsibility and mission of a major country, and it will become a powerful promoter of promoting the world's carbon peaking goal as soon as possible. Domestically, China has achieved positive results in controlling greenhouse gas emissions, promoting energy conservation and emission reduction in key areas, developing renewable energy, and accelerating ecological governance and land greening $[9,10]$. Han et al. analyzed the development trends and research focus of industry 5.0 in the future [11]. Jagatheesaperuma et al. focused on the research perspective towards deployment of Industry 5.0 [12]. However, problems such as unbalanced and inadequate 
TABLE 1: Related works.

\begin{tabular}{lc}
\hline No. & Content \\
\hline 1 & Factors affecting the return of migrant workers to green entrepreneurship \\
2 & Establishing a regression model \\
3 & Influence on the green entrepreneurial behavior \\
\hline
\end{tabular}

economic development, structural imbalances in highemission industries, large-scale manufacturing, and uncoordinated high-quality development are still prominent. The country needs to continue to promote low-carbon energy consumption, industrial restructuring, and improving manufacturing eco-efficiency.

Combining with the series of green carbon sink actions that China has carried out in recent years to address climate change at both the international and domestic levels, the proposed carbon peak and carbon neutral targets have richer connotations and significance. The proposal of the carbon peak and carbon neutral vision coincides with the major node. The construction of ecological civilization has achieved new progress and the efficiency of national governance has improved. The main economic and social development provides an important opportunity for the realization of the vision. In addition, the overall vision of carbon peaking and carbon neutrality also provides an effective driver for continuing to force China to deepen the green economy transformation, accelerate the adjustment of the energy structure, promote the construction of the carbon market, and coordinate with the construction of ecological civilization to form a joint force for joint realization.

2.2. Green Entrepreneurship. As an emerging research topic, the definition of the concept of green entrepreneurship has not yet been unified, and the terms used by scholars to describe green entrepreneurship are different. Academic names such as "environmental entrepreneurship," "green entrepreneurship," and "sustainable entrepreneurship" have appeared. In the definition of the concept of green entrepreneurship, scholars have defined it from different angles. Based on the perspective of entrepreneurial opportunity identification, Yuniriyanti et al. [13] believe that green entrepreneurship is a process by which companies identify, evaluate, and utilize business opportunities under the principles of sustainable development goals. Such business opportunities arise when the market fails. It is closely related to the environment [13]. Based on the perspective of entrepreneurial output, Hornsby et al. believe that, in a narrow sense, green entrepreneurship is a process of enterprise creation in which entrepreneurs play their subjective initiative and creatively provide environmentally friendly products [14]. In a broad sense, green entrepreneurship can be described as the development of enterprises. At each stage, through environmental innovation, an innovative, market-oriented, individual-driven form of value creation is present for providing environmentally friendly products [15]. Wang and Peng believe that green entrepreneurship refers to innovation or the creation of a green-oriented organization and emphasizes the need to create a green benefit (GVA) to protect the natural environment and increase the interests of corporate stakeholders. Green entrepreneurship is an entrepreneurial behavior for protecting the environment [16]. Chinese scholar Šneiderienè et al. combed and summarized the concept of green entrepreneurship by predecessors and pointed out that the connotation of green entrepreneurship is divided into broad and narrow sense [17]. The narrow sense of green entrepreneurship is only a short-term and partial entrepreneurship, which refers to the cost, innovative or marketing advantages are the motivation to achieve green, and in a broad sense, green entrepreneurship is comprehensive and of long term. It is a form of value creation, based on innovative environmental protection methods, market-oriented, driven by individuals, and "sustainable" as the goal.

Green entrepreneurship is a new way of entrepreneurship, and the internal operating mode of green entrepreneurial enterprises is different from traditional entrepreneurship. According to the research on green entrepreneurship they believe that green entrepreneurship is a process of creating green benefit (GVA), which must protect the natural environment and increase the interests of corporate stakeholders [18]. The realization of green benefit requires the use of the company's own advantages and the external favorable environment to achieve green operations in all aspects of the company's production and operation. Generally, the green entrepreneurial operation model includes five major aspects [19]. (1) Green input logistics: Green enterprises should avoid water, air, and soil pollution during the procurement process, use healthy and environmentally friendly materials, clean energy, and use energysaving technologies or processes to improve their greenness in warehousing and logistics to achieve ecological benefits. (2) Green production: Green production is the strict use of green technology and production processes in the production of green products or the provision of green services. (3) Green export logistics: Green output is mainly in the final link of production, strictly controlling and recycling byproducts, using green environmental protection materials for packaging, and harmless treatment of waste to achieve green products and services. (4) Green marketing: Green marketing refers to the design of marketing channels and the utilization of environmental protection technologies. It is necessary to consider and meet the environmental demands of consumers and society and realize the greening of the marketing network and the recycling of resources, to create profits while achieving sustainable operation. (5) Green service: The service itself and service-oriented green constitute the green service link. The first purpose is to avoid negative impacts on the environment during the use of products or the provision of services, while the latter purpose is to affect consumers' non-green consumption 
behaviors. Change and design some green services to guide consumers to develop the habit of green consumption. The basic framework and objectives of the green entrepreneurial operation model are shown in Figure 1.

In summary, green entrepreneurship, as an emerging research topic, is a new research field that has emerged at a certain stage of social and economic development and has not yet formed a unified theoretical system. In terms of research methods, qualitative analysis is mostly used, and most of the literature uses cases. There are few special studies on the green entrepreneurial behavior of agricultural enterprises. Regarding the research on the driving factors of corporate green entrepreneurship, most scholars tend to analyze from the perspective of a single factor, such as personal values, consumer needs, and institutional regulations [20]. In terms of corporate green entrepreneurial behavior research, there is a lack of specific quantitative indicators and very few empirical studies. The relevant conclusions, especially the research on behavioral influence factors, are not sufficiently persuasive, and they are still in the low-paradigm research stage. Based on this, this paper adopts the sample data of the green entrepreneurial behavior of migrant workers to construct a green entrepreneurial behavior evaluation index, which establishes a measurement model for the green entrepreneurial behavior index.

\section{Analysis of the Influencing Factors of Green Entrepreneurship by Returning Migrant Workers}

3.1. Data Sources. In order to better promote migrant workers to return to their hometowns to set up entrepreneurship, the migrant workers' return to set up entrepreneurship and implement the rural revitalization strategy; this paper designs a questionnaire on the factors affecting migrant workers' return to set up entrepreneurship. Statistics and analysis were carried out. 480 questionnaires were distributed to the central region in this survey, and 460 valid questionnaires were returned. The survey subjects included the new generation of migrant workers and the first generation of migrant workers, and the distribution was relatively even. The proportions of men and women are roughly equal. The selected migrant workers' industries include agricultural product sales, construction, clothing, handicrafts, service industries, business management, and helpers for farms. Therefore, the samples selected in this study have a certain level of representativeness, which provides an important basis for determining the practical obstacles for migrant workers to return to their hometowns to set up entrepreneurship and for this article to propose strategies to promote migrant workers to return to their hometowns to set up entrepreneurship. As an important force in promoting social development, whether the group of migrant workers will return to their hometown to set up entrepreneurship after graduation has received great attention from the society. According to the questionnaire survey data, the largest proportion of migrant workers is engaged in the construction industry, as high as $37 \%$. There is also a lot of agricultural products sales, accounting for $12.2 \%$. Handicrafts, service industries, business management, and helpers who help farms account for $9.8 \%, 7 \%, 4.3 \%$, and $4.5 \%$, respectively. In addition, this part is the high-quality returning entrepreneurial talents that the rural areas urgently need [21]. According to investigations and studies, most of the motives for migrant workers to return to their hometowns to set up entrepreneurship are due to the high pressure of survival in the city, while fewer people return to their hometowns to build their hometowns. Men's willingness to set up entrepreneurship is higher than women's. The biggest difficulty faced by migrant workers returning to set up entrepreneurship is insufficient funds. The willingness of high-educated migrant workers to start business is lower than that of low-educated migrant workers. The statistical results show that there are varying levels of obstacles and difficulties for migrant workers to return to set up entrepreneurship. On the other hand, these also provide us with some ideas for solving the practical obstacles for migrant workers to return to set up entrepreneurship as shown in Table 2.

\subsection{Characteristics of Migrant Workers' Willingness to Set Up} Green Entrepreneurship. After migrant workers have accumulated a certain amount of capital and experience, their willingness to set up entrepreneurship is very high, and the willingness of green entrepreneurship is relatively large in Figure 2. In addition, it can be seen from Table 3 that migrant workers and entrepreneurs prefer the green entrepreneurial model of family eco-farms and eco-tourism. It shows that the green management concept of migrant workers has continuously improved.

It can be seen from Table 4 that as the awareness of environmental protection continues to increase, consumers' demand for ecological products increases, and entrepreneurs' green entrepreneurial willingness increases, they will prefer environmentally friendly entrepreneurial projects. In addition, the government supervision is becoming more and stricter, the environmental investment is also increasing, and the penalties for environmental pollution behaviors have constantly strengthened, thus promoting the green entrepreneurship of migrant workers.

The source of resistance to the willingness of migrant workers starts a green entrepreneurship. It can be seen from Table 5 that migrant workers have limited abilities, no available superior resources, and insufficient funds for their own businesses. The lack of the relevant support policies and the poor ability to use the policies has led to their inability to obtain sufficient financial support. Therefore, some migrant workers are hindered from green entrepreneurship.

Through a descriptive analysis of 460 questionnaires on the status quo of migrant workers' green entrepreneurship, the status of migrant workers' green entrepreneurship is divided into three categories: migrant workers' green entrepreneurship human capital characteristics analysis, migrant workers' green entrepreneurship willingness characteristics, and migrant workers' green entrepreneurship issues. In this part, the analysis of the personal 


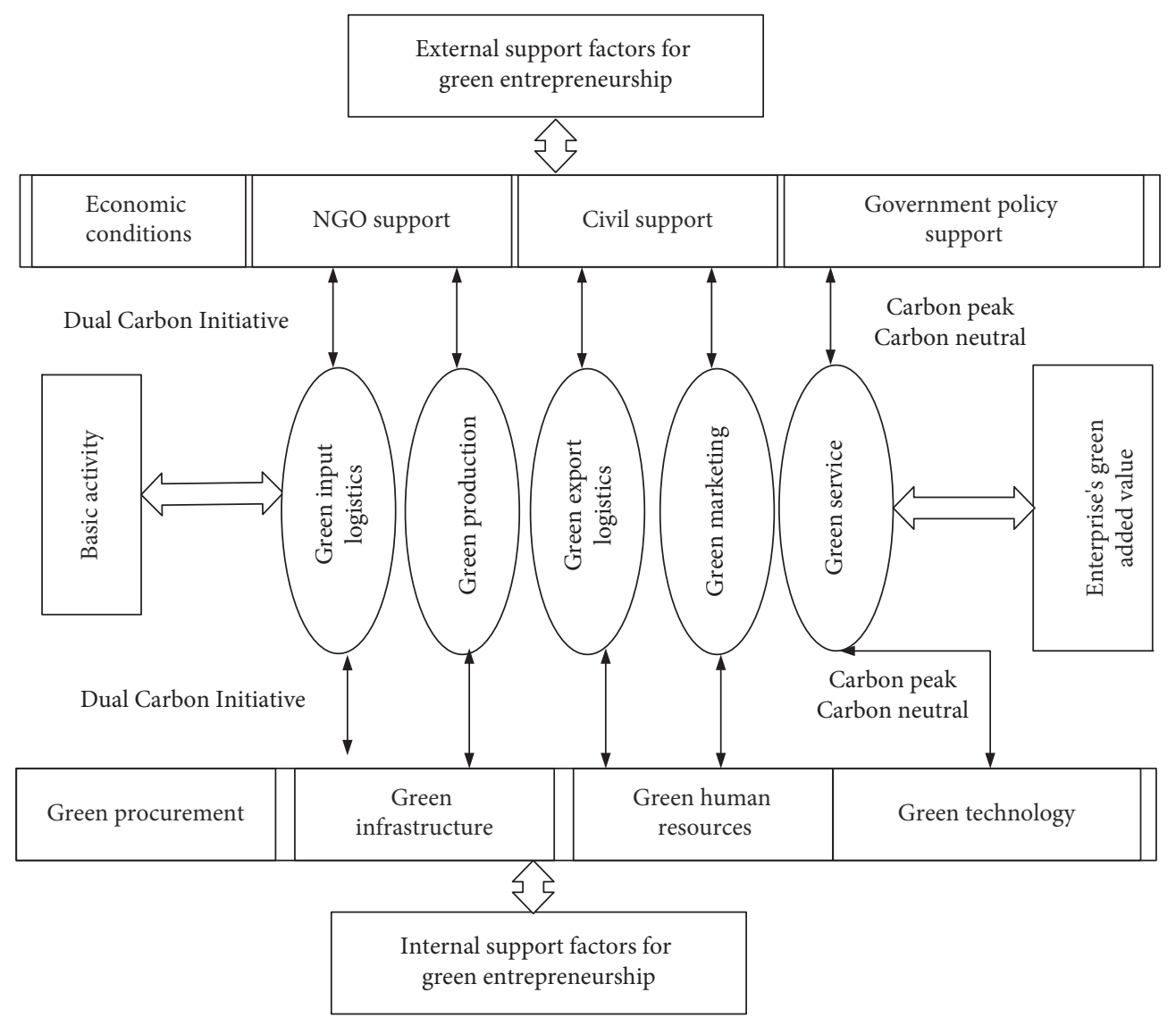

FIgURE 1: The operating model of green entrepreneurship.

TABLE 2: Staff composition of green entrepreneurship.

\begin{tabular}{lccc}
\hline Index & Code & Sample & Percentage (\%) \\
\hline \multirow{4}{*}{ Gender } & Male & 240 & 52.2 \\
& Female & 220 & 47.8 \\
& Sum & 460 & 100 \\
\hline \multirow{5}{*}{ Profession } & Agricultural product sales & 80 & 17.4 \\
& Clothing industry & 160 & 34.8 \\
& Handicraft & 80 & 17.4 \\
& Service industry & 70 & 15.2 \\
& Business management & 20 & 4.3 \\
& Farm helper & 50 & 10.9 \\
& Total & 460 & 100 \\
\hline
\end{tabular}

characteristics of migrant workers' green entrepreneurial human capital shows that migrant workers are mainly young and middle-aged, their education level is concentrated in junior high school, and they have few skills and training opportunities. The work income is low, and relatives and fellow villagers dominate the network. After analyzing the characteristics of migrant workers' green entrepreneurial willingness, it is found that migrant workers have a higher willingness to green entrepreneurship and prefer green entrepreneurial projects such as family ecological farms, ecotourism, and resource recycling. Among them, the increase of migrant workers' awareness of environmental protection and the increase in market demand for ecological products have promoted the increase of migrant workers' willingness

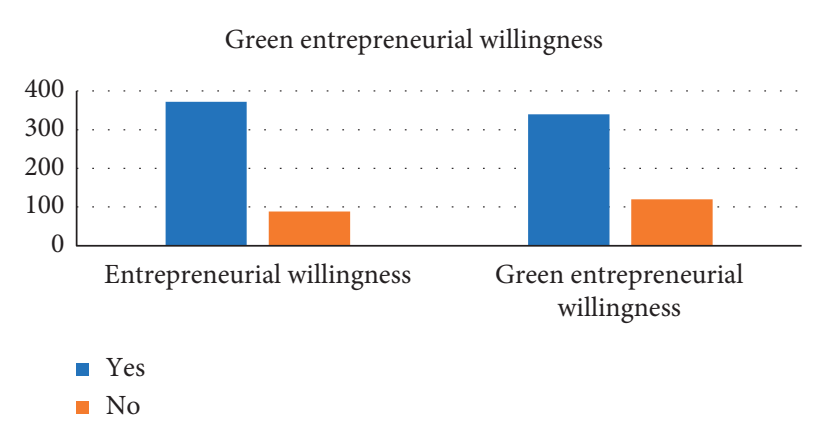

FIGURE 2: The survey of green entrepreneurial willingness.

to start green entrepreneurship. As more and more attention has been paid to environmental pollution, the government has increased its investment in environmental protection and strengthened penalties for environmental pollution behaviors, thereby increasing the initiative and enthusiasm of migrant workers' green entrepreneurial willingness. In addition, the education level is low, and the ability to learn new things is poor, which hinders the willingness of migrant workers to set up green entrepreneurship. Although China has given certain loans, subsidies, and other preferential policies to encourage migrant workers to start green entrepreneurship, the conditions of the preferential policies are harsh, and fewer migrant workers can enjoy preferential policies. In addition, because the social network of migrant workers has dominated by fellow villagers and relatives, the 
TABLE 3: Project preference of green entrepreneurship.

\begin{tabular}{lcc}
\hline Entrepreneurship type & No. & Percentage (\%) \\
\hline Waste recycling & 23 & 5 \\
Comprehensive utilization of resources & 46 & 10 \\
Family eco-farm & 184 & 40 \\
Eco-tourism & 138 & 30 \\
Dual-carbon farming and forestry & 23 & 5 \\
Others & 46 & 10 \\
Sum & 460 & 100 \\
\hline
\end{tabular}

TABLE 4: Power source of green entrepreneurship.

\begin{tabular}{lll}
\hline Power source & No. & Percentage (\%) \\
\hline Increasing awareness of environmental protection & 253 & 55 \\
Strong desire for green entrepreneurship & 230 & 50 \\
Project investment with dual-carbon background & 207 & 45 \\
Government investment in environmental protection & 207 & 45 \\
Penalties for environmental pollution & 184 & 40 \\
Green product demand & 184 & 40 \\
\hline
\end{tabular}

TABLE 5: Resistance source of green entrepreneurship.

\begin{tabular}{lll}
\hline Limited understanding of dual-carbon protection & No. & Percentage (\%) \\
\hline I do not understand the loan policy & 322 & 70 \\
Poor natural conditions & 253 & 55 \\
Policy utilization & 184 & 40 \\
Fund acquisition & 184 & 40 \\
Limited understanding of dual-carbon protection & 138 & 30 \\
\hline
\end{tabular}

channels for obtaining information are single, and policies cannot be correctly understood and used flexibly. Marketoriented analysis is derived from accumulated experience and cannot adapt to the development of the times, which makes its green entrepreneurial path difficult.

3.3. Empirical Model. According to the previous relevant analysis, it is concluded that the willingness of migrant workers to start a green business is affected by factors such as the characteristics of ecological capabilities, the characteristics of the external environment, and the characteristics of policy support. Therefore, the function expression can be set as follows:

$$
\begin{array}{r}
\widehat{Y}=\widehat{\beta}+\widehat{\beta}_{1} X_{1}+\ldots+\widehat{\beta}_{9} X_{9} . \\
\text { Among them, } \widehat{y}=\left[\begin{array}{c}
y_{1} \\
y_{2} \\
\vdots \\
y_{1}
\end{array}\right], \widehat{\beta}=\left[\begin{array}{c}
\beta_{0} \\
\beta_{1} \\
\vdots \\
\beta_{9}
\end{array}\right] .
\end{array}
$$

When migrant workers have no ecological entrepreneurial willingness, $\widehat{Y}=0$. When migrant workers are willing to start an ecological business, $\widehat{Y}=1$. Among them, X1, respectively, represents 9 variables in the three types of characteristics of migrant workers' green entrepreneurship capabilities, external environment characteristics, and policy support characteristics. The specific variables of each influencing factor in the regression model are explained in Table 6 .

Most of the variables in the regression analysis are the same as those in the correlation analysis. Some of the variables are explained as follows. First, the variable of education level is divided into "below elementary school $=1$, junior high school and above $=3$, bachelor's level and above $=5$," among which "junior high school," "senior high school (secondary school)," and "junior college" in the questionnaire options are classified as "junior high school and above $=3$." Because it is an unfavorable cause, the option is classified as an influencing factor that hinders entrepreneurial willingness, and the answer is "yes." It is 1 and the others are 0. The variable "work" involves more occupations in the questionnaire, and it is divided into primary, secondary, and tertiary industries. Among them, the options are "company management, sales staff," "private small business owners," and "business owner" and "contractor" are classified as "industry" with a value of 2. "Waiter," "cashier," and "security, cleaning, and driver" are classified as "service industry" with a value of 3 . "Agricultural" is classified as the value of "agriculture" is 1 . The value of "others" is 3. Secondly, the variable "social capital" is replaced by the number of friends, and more migrant workers interact with each other. The social capital is higher, and the opportunity for green entrepreneurship is greater [22]. The willingness of green entrepreneurship is stronger. In addition, in the variables, according to the opinion measurement method, the options have assigned a value of 1-5 points. For example, for the variable "protect environmental awareness," the questionnaire asks "Your awareness of protecting the environment is increasing," and the answer options are "very nonconforming," "nonconforming," "general," "basically conforming," and 
TABLE 6: Characteristic of migrant workers' green entrepreneurial ability.

\begin{tabular}{|c|c|c|c|c|}
\hline Variable name & Explanation & $\begin{array}{l}\text { Mean } \\
\text { value }\end{array}$ & $\begin{array}{l}\text { Standard } \\
\text { deviation }\end{array}$ & Direction \\
\hline Education & $\begin{array}{c}\text { Junior high school and below 1, junior high school and above } 3 \text {, } \\
\text { high school and above } 5 .\end{array}$ & 2.8 & 0.7 & $+1-$ \\
\hline Jobs & Agriculture $=1$, service industry $=3$, others $=5$ & 2.7 & 1.2 & $+/-$ \\
\hline Social capital & None $=1$, yes $=3$ & 3.0 & 0.9 & $+1-$ \\
\hline Educational investment & No investment $=1$, investment $=3$. & 3.5 & 0.8 & $+1-$ \\
\hline Bring up & $\mathrm{No}=1$, yes $=3$ & 1.6 & 0.7 & $+1-$ \\
\hline Self-protection & $\begin{array}{l}\text { Whether one's own ability hinders entrepreneurship, yes }=1 \text {, } \\
\text { no }=0 .\end{array}$ & 0.7 & 0.5 & $+1-$ \\
\hline $\begin{array}{l}\text { Environmental protection } \\
\text { awareness }\end{array}$ & Yes $=3$, no $=1$ & 3.6 & 0.9 & $+/-$ \\
\hline Entrepreneurial resources & Up to standard $=3$, not up to standard $=1$ & 3.2 & 1.1 & $+1-$ \\
\hline Ability to integrate resources & $\begin{array}{c}\text { Junior high school and below 1, junior high school and above } 3 \text {, } \\
\text { high school and above } 5 .\end{array}$ & 3.5 & 0.9 & $+/-$ \\
\hline
\end{tabular}

"very conforming." The score is higher, indicating that migrant workers' awareness of environmental protection has continuously enhanced, thereby promoting their green entrepreneurial willingness.

\subsection{Analysis of Influencing Factors of Peasant Workers' Green Entrepreneurship Willingness}

(1) From the perspective of social science research, the model fits well. The awareness of environmental protection is stronger and the ability to integrate resources is stronger; the willingness of migrant workers is stronger to set up green entrepreneurship. In terms of the characteristics of its own green entrepreneurial ability, environmental awareness, ability to integrate resources, and its own ability have passed the significance test and are basically consistent with the previous expected direction, while the education level, work, training, educational skills investment, and social capital are not significant. Because migrant workers have been working abroad for a long time, their ideology and their own abilities are constantly changing, and they have certain green entrepreneurial resources and abilities. According to the survey, although migrant workers work harder and have low incomes, their environmental protection awareness and ideological awareness continue to increase. For further improvement, therefore, migrant workers are willing to make full use of their own resources to set up entrepreneurship and constantly improve their own resources and strengthen their own resource integration capabilities, to promote a stronger willingness to green entrepreneurship.

(2) The limited ability and poor natural conditions hinder the process of migrant workers' green entrepreneurial willingness.

According to the survey, the limited ability and poor natural conditions have become the main obstacles to set up green entrepreneurship. As migrant workers are mainly educated in junior high school, they have relatively little knowledge and insights, and their ability to accept new things and learn is weak. The ability to integrate resources and optimize their own resources is relatively weak, and the channels for obtaining information are single. In addition, some companies do not pay attention to environmental protection and waste of resources, which makes the natural conditions worse and worse, and the migrant workers have fewer and fewer resources and fewer and fewer entrepreneurial resources, which hinders the process of green entrepreneurship for migrant workers.

(3) From the characteristics of the external environment, the green entrepreneurial environment and poor natural conditions have passed the significance test. Among them, the green entrepreneurial environment is highly significant. However, the awareness of purchasing environmental products and the demand for ecological products are not obvious. Continuously improve relevant laws and systems, resolve the risks of migrant workers' green entrepreneurship, and provide guarantees for migrant workers' green entrepreneurship, thereby enhancing their willingness to engage in green entrepreneurship.

(4) The more the government invests in environmental protection, the greater the subsidy tax support is. In terms of government policy support, environmental protection investment and assistance organizations have passed the significance test, while the significance of loans, environmental pollution penalties, publicity, and subsidy taxation is not obvious. According to the survey, the lack of entrepreneurial funds hinders migrant workers from starting green entrepreneurship. The government should increase investment in environmental protection and reduce the pressure on migrant workers' green entrepreneurial funds. Moreover, as the government's investment in environmental protection increases, migrant workers' awareness of environmental 
TABLE 7: Variables in the equation.

\begin{tabular}{|c|c|c|c|c|c|c|}
\hline & $\mathrm{B}$ & SE & Ws & $\mathrm{df}$ & Sig & Exp \\
\hline Education & -0.26 & 0.15 & 3.2 & 1.00 & 0.07 & 0.74 \\
\hline Jobs & -0.05 & 0.1 & 0.32 & 1.00 & 0.60 & 0.95 \\
\hline Social capital & 0.15 & 0.1 & 1.6 & 1.00 & 0.12 & 1.1 \\
\hline Educational skills investment & -0.1 & 0.12 & 0.8 & 1.00 & 0.23 & 1.2 \\
\hline Environmental protection awareness & 0.26 & 0.11 & 6.2 & 1.00 & 0.37 & 0.9 \\
\hline Own entrepreneurial resources & -0.16 & 0.1 & 2.95 & 1.00 & 0.10 & 0.8 \\
\hline Ability to integrate resources & 0.25 & 0.13 & 4.7 & 1.00 & 0.03 & 1.3 \\
\hline Entrepreneurial environment & 0.48 & 0.12 & 9.6 & 1.00 & 0.01 & 1.6 \\
\hline Poor natural conditions & 0.00 & 0.1 & 2.8 & 1.00 & 0.1 & 1.5 \\
\hline Environmental product purchase awareness & 0.16 & 0.1 & 0.00 & 1.00 & 0.97 & 1.1 \\
\hline Ecological product demand & 0.18 & 0.12 & 2.86 & 1.00 & 0.09 & 1.2 \\
\hline Loan & 0,15 & 0.11 & 1.83 & 1.00 & 0.18 & 1.20 \\
\hline Environmental protection investment & 0.28 & 0.12 & 5.83 & 1.00 & 0.03 & 1.27 \\
\hline Subsidy & -0.08 & 0.18 & 3.16 & 1.00 & 0.56 & 1.64 \\
\hline Environmental pollution penalty & 0.04 & 0.15 & 0.08 & 1.00 & 0.83 & 1.05 \\
\hline
\end{tabular}

TABLE 8: Model test results.

\begin{tabular}{|c|c|c|c|c|c|}
\hline Variable & 0.1 & 0.25 & 0.5 & 0.75 & 0.9 \\
\hline Enterprise size & -0.26 & -0.22 & -0.21 & -0.14 & -0.41 \\
\hline Whether the company is listed & -0.20 & -0.06 & -0.13 & -0.15 & -0.22 \\
\hline Corporate assets & -0.05 & -0.04 & -0.02 & 0.01 & 0.04 \\
\hline Enterprise nature (state-owned/collective) & -0.23 & 0.21 & 0.15 & 0.18 & 0.09 \\
\hline Enterprise nature (private) & -0.04 & 0.08 & 0.14 & 0.15 & 0.08 \\
\hline Industry (plantation) & 0.1 & 0.06 & 0.09 & 0.01 & 0.03 \\
\hline Industry (aquaculture) & -0.04 & -0.01 & -0.07 & -0.01 & -0.08 \\
\hline Life cycle (growth period) & -0.21 & -0.09 & -0.11 & 0.01 & 0.14 \\
\hline Life cycle (mature period) & -0.23 & -0.11 & -0.17 & 0.00 & 0.08 \\
\hline Life cycle (transition period) & -0.14 & -0.09 & -0.13 & 0.04 & 0.11 \\
\hline Policy support & 0.19 & 0.22 & 0.21 & 0.21 & 0.14 \\
\hline Environmental regulation & 0.17 & 0.18 & 0.22 & 0.27 & 0.23 \\
\hline
\end{tabular}

protection has also increased. It can be seen from Table 7 that the support organization passed the significance test, indicating that the support organization is a significant factor influencing the green entrepreneurship of migrant workers. The establishment of a support organization will unite the government, universities, and scientific research institutions, leading enterprises and green entrepreneurial experts to provide assistance. It has made up for the shortcomings of migrant workers' lack of ability, improved their green entrepreneurial skills, enhanced the competitiveness and success rate of green entrepreneurship, and drove migrant workers to engage in green entrepreneurship.

\section{Results and Discussion}

This paper puts the four environmental variables of policy support, environmental regulation, stakeholder pressure, and corporate environmental awareness into the model for quantile regression testing and gets the model results, as shown in Table 8 . The table lists the regression results of each variable at the $0.1,0.25,0.5,0.75$, and 0.9 quantiles. Through the differential performance of each variable at different distribution points, it is possible to have a more comprehensive and in-depth understanding of the entrepreneurial environment and corporate characteristics for corporate green entrepreneurship [23]. This paper uses stata12 software to estimate, and the results obtained are shown in Table 8.

The variable of enterprise scale has a negative impact on the level of greening of enterprise production and operation, and the impact is more significant. The quantile regression coefficient of this variable shows a trend of rising first, reaching the maximum value at the $75 \%$ quantile, and then rapidly decreasing, passing significance at the $10 \%, 25 \%$, $50 \%$, and $90 \%$ quantiles. There is a greater level of complexity and inefficiency in environmental improvement, resulting in a low level of greenness in its production and operations. The variable of the nature of the enterprise has an impact on the level of greening of the production and operation of the enterprise. Among them, the nature variable of the private enterprise has a positive effect on the level of greening of the production and operation of the enterprise. The life cycle of an enterprise has a significant impact on the green level of production and operation of the enterprise. Among them, the mature stage enterprise variables have a negative impact on the level of green production and operation of the enterprise, and the quantile regression coefficient shows an increase first and then a downward and 
rapid upward trend. This variable has passed the significance test at the $50 \%$ quantile, and the coefficient is negative, indicating that the production and operation of the start-up enterprises are greener. The possible reason is that when the company is in the initial stage, it faces instability and urgently needs the support of shareholders and the affirmation of consumers. This makes managers have stricter requirements on the company in terms of raw material procurement, production management, and staff quality and skill training. Therefore, it shows a higher level of greenness in terms of product quality and service. The regression coefficient of the policy support variable is positive, and it has passed the significance test at each quantile point. The quantile regression coefficient shows a trend of first rising, reaching the maximum value at the $25 \%$ quantile, and then slowly decreasing. At the $25 \%$ quantile, the policy support environment will improve the level of green production and operation of the company every time the environment is improved. The government can provide financial support, financing support, and tax relief for enterprises that implement environmental protection activities. It has a good influence on the green entrepreneurial behavior of enterprises and enhances the green level of enterprise production and operation.

\section{Conclusions}

Green entrepreneurship is conducive to improving the forest ecological environment and stimulating rural areas to get rid of poverty and becoming rich, thereby reducing the government's pressure on ecological compensation. The green entrepreneurship of migrant workers has promoted the construction of rural infrastructure and public utilities and accelerated the transformation of agricultural development methods. The contributions of this research are as follows. Migrant workers encouraged starting their businesses; it will help solve the problems of empty old people, left-behind children, and left-behind women. Secondly, the regression coefficient of the environmental regulation variable is positive, and it has passed the significance test at each quantile point. Hence, strict environmental management rules and regulations can force enterprises to implement green entrepreneurship and promote the improvement of the green level. The quantile regression coefficient shows a trend of rising first, reaching the maximum value at the $75 \%$ quantile, and then slowly decreasing. Based on the above, the migrant workers' green entrepreneurial willingness is related to environmental protection awareness, green entrepreneurial environment, their own resource integration ability, environmental protection investment, and other factors. Among them, the green entrepreneurial environment and assistance organizations are significant influencing factors. This article combines the effective ways of encouraging migrant workers to green entrepreneurship in different regions. It proposes practical and reasonable relevant countermeasures to encourage migrant workers to green entrepreneurship and enhance their green entrepreneurship willingness in the future.

\section{Data Availability}

All data included in tables are available upon request by contact with the corresponding author.

\section{Conflicts of Interest}

The authors declare that there are no conflicts of interest regarding the publication of this paper.

\section{References}

[1] M. Zid, A. T. Alkhudri, A. R. Casmana, A. Marini, and A. Wahyudi, "Ex migrant workers of international women and social entrepreneurship: study at kenanga village in Indramayu Regency in West Java Province in Indonesia," International Journal of Advanced Science and Technology, vol. 29, 2020.

[2] J. Fitra and D. Rizana, "Strategi pemberdayaan kewirausahaan mantan buruh migran perempuan di kabupaten kebumen," Fokus Bisnis: Media Pengkajian Manajemen dan Akuntansi, vol. 18, no. 1, pp. 36-42, 2019.

[3] J. Chen, R. Liu, and X. Luo, "Research on incentive mechanism of returning migrant workers to set up entrepreneurship under the background of mass entrepreneurship and innovation," in Proceedings of the 5th International Conference on Economic and Business Management, Jilin, China, February 2020.

[4] C. Mukonza, "An analysis of factors influencing green entrepreneurship activities in South Africa," Advances in African Economic, Social and Political Development, United Nations University Institute for Natural Resources in Africa, Accra, Ghana, pp. 47-67, 2020.

[5] B. Ranasinghe and R. Ajward, "Factors affecting green entrepreneurial intention among small and medium enterprise owners in western province, Sri Lanka," in Proceedings of the 12th Internatinal Research Conference of General Sir John Kotelawala Defence University, Dehiwala-Mount Lavinia, Sri Lanka, September 2019.

[6] Al-Dmour, H. Rand, T. Mohammed, and H. H. Al-Dmour, "Factors influencing students' intentions towards entrepreneurship: comparative study," International Journal of Sustainable Entrepreneurship and Corporate Social Responsibility (IJSECSR), vol. 4, no. 1, pp. 1-26, 2019.

[7] M. X. Wang, "Research on the route of entrepreneurship education for migrant workers returning home from the perspective of new urbanization," in Proceedings of the $3 \mathrm{rd}$ International Conference on Economy, Management and Education Technology (ICEMET 2017, Jinan, China, October 2017.

[8] J. E. Amorós, R. Basco, and G. Romaní, "Determinants of early internationalization of new firms: the case of Chile," The International Entrepreneurship and Management Journal, vol. 12, no. 1, pp. 283-307, 2016.

[9] A. Davari, A. Emami, V. Ramadani, and S. Taherkhani, "Factors influencing academic entrepreneurship: a case-based study," Journal of Science and Technology Policy Management, vol. 9, no. 3, pp. 284-295, 2018.

[10] P. N. Srinivasu, A. K. Bhoi, R. H. Jhaveri, G. T. Reddy, and M. Bilal, "Probabilistic deep Q network for real-time path planning in censorious robotic procedures using force sensors," Journal of Real-Time Image Processing, vol. 18, no. 5, pp. 1773-1785, 2021. 
[11] J. Q. Han, L. Hong-Qiang, and D. X. Zhong, "Analysis on internal rules of industrial revolution development and trends of future industry 5.0," Information Technology and Informatization, vol. 8, no. 4, 2016.

[12] S. K. Jagatheesaperuma, M. Rahouti, K. Ahmad, M. Guizani, and A. Al-Fuqaha, "The duo of artificial intelligence and big data for industry 4.0: review of applications, techniques, challenges, and future research directions," IEEE Internet of Things Journal, 2021, https://arxiv.org/abs/2104.02425.

[13] E. Yuniriyanti, R. Sudarwati, and B. Nurdewanto, "Philanthropy as a form of social entrepreneurship in an effort to empower ex migrant women workers: study at Malang district, Indonesia," The International Journal of Humanities \& Social Studies, vol. 8, no. 9, 2020.

[14] J. S. Hornsby, J. Messersmith, M. Rutherford, and S. Simmons, "Entrepreneurship everywhere: across campus, across communities, and across borders," Journal of Small Business Management, vol. 56, no. 1, pp. 4-10, 2017.

[15] M. O. Faruk, N. Hassan, and N. Islam, "Factors influencing the development of social entrepreneurship in Bangladesh," SSRN Electronic Journal, 2016, https://ssrn.com/ abstract=2856210 or http://dx.doi.org/10.2139/ssrn.2856210.

[16] J. Wang and C. Peng, "Factors influencing university students' coastal ecology and environmental-friendly entrepreneurship in coastal universities," Journal of Coastal Research, vol. 109, no. sp1, 2020.

[17] A. Šneiderienè, R. Viederyte, and L. Abele, "Green growth assessment discourse on evaluation indices in the European Union," Entrepreneurship and Sustainability Issues, vol. 8, no. 2, pp. 360-369, 2020.

[18] E. Wahyono, L. M. Kolopaking, M. C. T. Sumarti, and A. V. S. Hubeis, "Jaringan digital dan pengembangan kewirausahaan sosial buruh migran perempuan," Jurnal ILMU KOMUNIKASI, vol. 16, no. 1, pp. 57-76, 2019.

[19] M. Talić, M. Ivanović-Đukić, and T. Rađenović, "Sustainable entrepreneurship: creating opportunities for green products development," Economics of Sustainable Development, vol. 4, no. 2, pp. 1-13, 2020.

[20] R. Yuniarto, "From entrepreneurship to social activist: the role of Indonesian migrant entrepreneurs in taiwan and socio- economic functions of return-migrant entrepreneurship in Malang, east java," Entrepreneurship-Trends and Challenges, vol. 2, 2018.

[21] A. Tleuberdinova, Z. Shayekina, D. Salauatova, and S. Pratt, "Macro-economic factors influencing tourism entrepreneurship: the case of Kazakhstan," Journal of Entrepreneurship, vol. 30, no. 1, pp. 179-209, Article ID 097135572098143, 2021.

[22] V. O. Alejandra, G. E. Laura, Z. H. Manuel, and G. L. Cruz, "Specification of a Local Entrepreneurship Model," Revista de Investigación Académica Sin Frontera: División de Ciencias Económicas y Sociales, vol. 33, pp. 1-16, 2020.

[23] T. Khan, K. Singh, M. H. Hasan et al., "ETERS: a comprehensive energy aware trust-based efficient routing scheme for adversarial WSNs," Future Generation Computer Systems, vol. 125, pp. 921-943, 2021 